\title{
IMPLEMENTASI ERP SAP DALAM PEMBUATAN REPORT DEMOGRAFI ORGANISASI (Studi Kasus PT. Krakatau Steel (Persero) Tbk.)
}

\author{
Ilham Bashirudin ${ }^{1)}$, Erlangga Fausa ${ }^{2)}$, Amarria Dila Sari $^{3)}$ \\ Sr.Manager Organization Design, PT.Krakatau Steel (Persero) Tbk ${ }^{l}$. \\ Jl. Industri No.5 Cilegon Banten 42435 \\ Jurusan Teknik Industri, Fakultas Teknologi Industri, Universitas Islam Indonesia ${ }^{2,3)}$ \\ Jl. Kaliurang Km.14,5, Sleman, Yogyakarta, 55584 \\ Email :ibashirudin@gmail.com ${ }^{1}$,865220102@uii.ac.id ${ }^{2}$,amarria@uii.ac.id ${ }^{3}$
}

\begin{abstract}
The demographics of an organization have a positive influence on organizational commitment that ultimately affects the performance of an organization. The absence of such information will result in significant lack of essential information for management in organizational optimization The following journals explain the implementation of SAP ERP in making an organization demographic report, where the use of the software can bypass the drafting process which initially requires a long process and long time (average time 30 minutes) becomes a short process (average time less than 1 minute) or there is a 30x acceleration of time. In addition, there are also benefits of real time output from the hassle of organizational demography. Increasing the speed of report preparation shows that SAP ERP provides great benefits for the organization in running its business processes.
\end{abstract}

Keywords: ERP, SAP, Busines Process, Organization, Demography.

\section{PENDAHULUAN}

Perusahaan selalu berusaha mencari dan menerapkan strategi terbaik untuk bersaing dengan perusahaan lain sehingga dapat bertahan diera bisnis yang kompetitif. Pada umumnya strategi yang dipakai oleh perusahan yang terdahulu adalah strategi untuk kegiatan operasional atau kegiatan eksternal. Akan tetapi, sebagian besar perusahaan global dengan sistem terbaru mengadopsi strategi yang digunakan untuk kekuatan internal atau eksternal.

Untuk menghadapi ini, sebagian besar perusahaan menerapkan paradigma komputasi, yakni mengadaptasi bisnis yang berbasis teknologi informasi (TI) yang berdasarkan infrastruktur sehingga mampu meringankan perubahan operasional yang terjadi (Bernal Bernabe et al., 2014). Salah satu perusahaan yang menerapkan sistem berbasis ERP SAP adalah PT. Krakatau Steel (Persero) Tbk.

\section{TINJAUAN PUSTAKA}

\subsection{Organisasi}

Menurut para ahli terdapat beberapa pengertian organisasi sebagai berikut :

1. Stoner mengatakan bahwa organisasi adalah suatu pola hubungan - hubungan yang melalui mana orang - orang di bawah pengarahan atasan mengejar tujuan bersama.

2. James D. Mooney mengemukakan bahwa organisasi adalah bentuk setiap perserikatan manusia untuk mencapai tujuan bersama.

3. Chester I. Bernard berpendapat bahwa organisasi adalah merupakan suatu sistem aktivitas kerja sama yang dilakukan oleh dua orang atau lebih.

4. Stephen P. Robbins menyatakan bahwa Organisasi adalah kesatuan (entity) sosial yang dikoordinasikan secara sadar, dengan sebuah batasan yang relatif dapat diidentifikasi, yang bekerja atas dasar yang relatif terus menerus untuk mencapai suatu tujuan bersama atau sekelompok tujuan. 
5. Sebuah organisasi dapat terbentuk karena dipengaruhi oleh beberapa aspek seperti penyatuan visi dan misi serta tujuan yang sama dengan perwujudan eksistensi sekelompok orang tersebut terhadap masyarakat. Organisasi yang dianggap baik adalah organisasi yang dapat diakui keberadaannya oleh masyarakat disekitarnya, karena memberikan kontribusi seperti; pengambilan sumber daya manusia dalam masyarakat sebagai anggota anggotanya sehingga menekan angka pengangguran.

Sehingga unsur - unsur yang ada dalam organisasi dari pengertian diatas adalah tujuan, orang, dan sistim aktivitas. Lebih lanjut mengenai unsur - unsur organisasi dan kaitannya dijelaskan oleh five star model oleh Jay R. Galbraith (Galbraith, Jay R. Organization, 1977).

\subsection{Demografi}

Menurut Tarigan, S. (2011), lingkungan umum pada lingkungan organisasi merupakan kondisi eksternal yang luas yang dapat mempengaruhi organisasi serta berpengaruh secara tidak langsung terhadap kinerja organisasi.

Menurut Nanda dkk (2011), lingkungan eksternal makro meliputi berbagai faktor, antara lain kondisi ekonomi, politik dan hukum, sosial budaya, demografi, teknologi dan kondisi global yang mungkin mempengaruhi organisasi. Perubahan lingkungan umum biasanya tidak mempunyai dampak sebesar perubahan lingkungan khusus, namun demikian manajer harus memperhatikannya ketika merencanakan, mengorganisasi, mengarahkan serta mengendalikan aktivitas organisasi bisnis.

Kondisi demografi mencakup kebiasaan yang berlaku dalam karakteristik fisik dari populasi, seperti jenis kelamin, usia, tingkat pendidikan, lokasi geografis, pendapatan, konsumsi keluarga.

Perubahan pada karakteristik karakteristik ini dapat berpengaruh pada kebijakan manajemen perusahaan dalam merencanakan, mengorganisasikan, memimpin dan mengontrol organisasi bisnisnya.

\subsection{Demografi dan Komitmen Organisasi}

Faktor - faktor dalam demografi seperti usia, jenis kelamin, status perkawinan, pendidikan dan job tenure dimasukan pada banyak penelitian dari dampak dari faktor demografi terhadap komitmen organisasi. Nifadkar and Dongre menemukan bahwa usia, jenis kelamin, status perkawinan dan tenure positif berhubungan, sedangkan tingkat pendidikan tidak berhubungan terhadap komitmen organisasi di India. (Kónya, dkk, 2016).

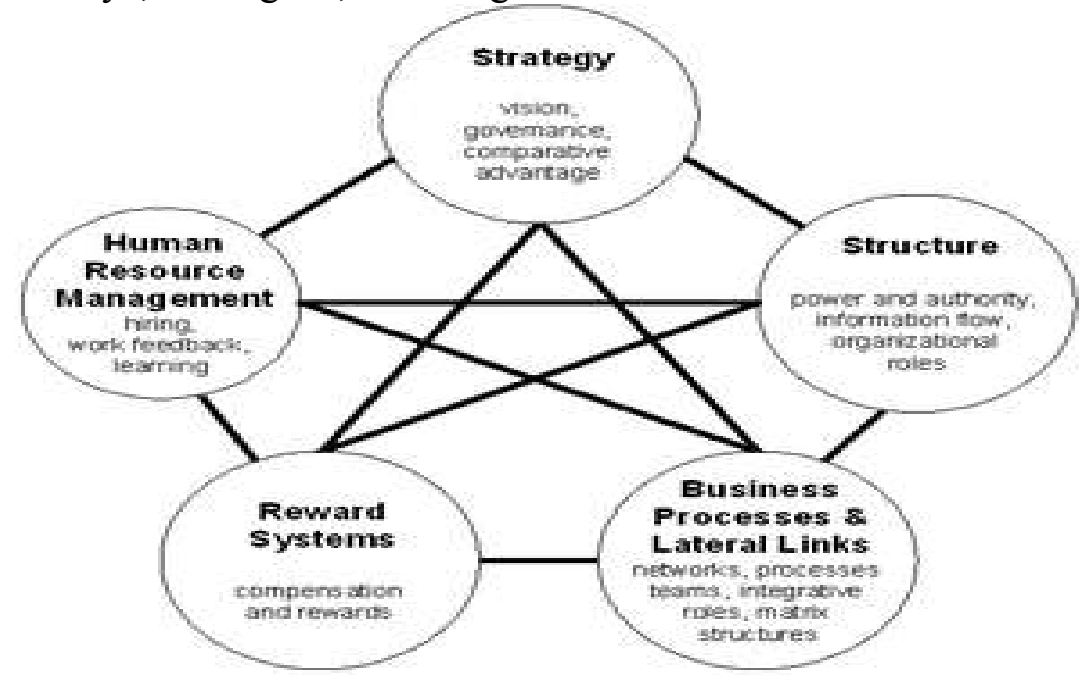

Gambar 1. The Star Model. 
Dalam jurnal tersebut diperoleh hasil bahwa tidak ditemukan perbedaan yang signifikan antara pria dan wanita untuk beberapa variabel. Namun, terdapat hubungan dari usia, pendidikan, tenure dalam organisasi dan lama waktu bekerja terhadap komitmen organisasi, dapat diperjelas dengan the star model dari Galbraith (1977) seperti yang ditunjukkan pada gambar 2.

Maka demografi mengenai komposisi yang berisikan usia, pendidikan, lama bekerja dan masa jabatan menjadi suatu hal yang perlu diperhatikan bagi organisasi dalam rangka mencapai komitment yang telah dituangkan dalam pilar strategi.

Sehingga informasi mengenai demografi seperti yang disebutkan diatas menjadi suatu informasi kritikal yang apabila tidak ada akan menyebabkan kurangnya informasi bisnis yang sangat esensial (lack of essential business information).

\subsection{Sistem}

Istilah sistem berasal dari bahasa Yunani "systema" yang artinya suatu keseluruhan yang kompleks yang disatu padukan ( $a$ complex a whole put together). Menurut McLeod, "sistem adalah sekelompok elemen - elemen yang terintegrasi dengan tujuan yang sama untuk mencapai tujuan" (Yakub, 2012).
Dengan demikian sistem merupakan bagian dari suatu jaringan kerja dari prosedur dan komponen pendukung yang saling berhubungan untuk melakukan suatu kegiatan atau tujuan tertentu. Sistem yang baik memiliki beberapa karakteristik sistem yang mempengaruhinya, diantaranya :

a. Fleksibel, merupakan sistem yang terstruktur dan terorganisir dengan baik, namun sebaiknya cukup fleksibel agar lebih mudah disesuaikan dengan keadaan yang sering berubah.

b. Mudah diadaptasikan, yaitu sistem yang cepat mudah diadaptasikan dengan kondisi baru tanpa mengubah sistem yang lama maupun mengganggu fungsi utamanya.

c. Sistematis yaitu sistem yang dibuat tidak akan mempersulit aktivitas pekerjaan yang telah ada.

d. Fungsional yaitu sistem yang dapat membantu mencapai tujuan yang telah ditentukan.

e. Sederhana yaitu sistem yang mudah dipahami dan dapat dilaksanakan.

f. Pemanfaatan sumber daya yang optimal yaitu sistem yang dirancang dengan baik akan menjadikan penggunaan sumber daya yang dimiliki organisasi dapat dioptimalkan pemanfaatannya (Sukoco, 2007).

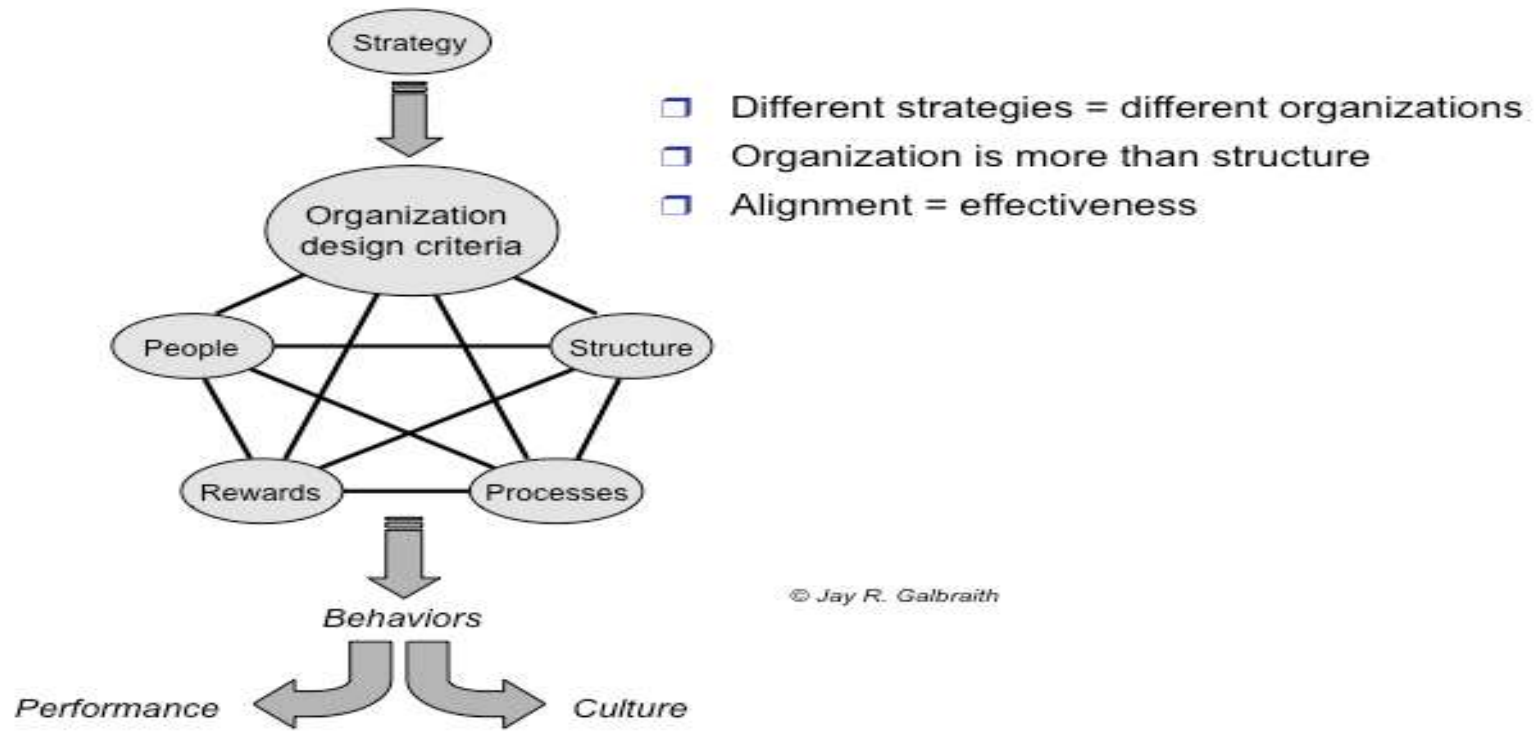

Gambar 2. Efek Desain Organisasi Terhadap Perilaku dan Budaya. 


\subsection{Proses Bisnis}

Davenport (1993) mendefinisikan proses bisnis sebagai "aktivitas yang terukur dan terstruktur untuk memproduksi output tertentu untuk kalangan pelanggan tertentu. Terdapat didalamnya penekanan yang kuat pada "bagaimana" pekerjaan itu dijalankan disuatu organisasi, tidak seperti fokus dari produk yang berfokus pada aspek "apa".

Suatu proses oleh karenanya merupakan urutan spesifik dari aktivitas kerja lintas waktu dan ruang, dengan suatu awalan dan akhiran dan secara jelas mendefinisikan input dan output.

\subsection{Enterprise Resources Planning (ERP)}

Menurut O'Brien dan Marakas (2007:320), "ERP is the technological backbone of e-business, an enterprisewide transaction framework with links into sales order processing, inventory management and control, production and distribution planning and finance".

Menurut Wallace, T. F., dan Kremzar (2001), "Enterprise Resource Planning is a direct outgrowth and extension of Manufacturing Resource Planning and, as such, includes all of MRP II's capabilities. ERP is more powerful in that it : a) applies a single set of resource planning tools across the entire enterprise, b) provides real-time integration of sales, operating, and financial data, and c) connects resource planning approaches the extended supply chain of customers and suppliers".

Berdasarkan beberapa pengertian mengenai ERP diatas dapat disimpulkan bahwa ERP merupakan sebuah sistem yang didesain untuk mengintegrasi semua kegiatan internal dan eksternal perusahaan yang memungkinkan mengakses data secara waktu nyata (real time). (Utami, S. S., \& Susilo, H, 2016).

\subsection{Benefit ERP}

Seperti yang telah dijelaskan di atas bahwa Enterprise Resource Planning (ERP) sistem adalah alat untuk mengoptimalkan, standarisasi, dan mengintegrasikan proses bisnis untuk mempercepat akses ke sumber daya umum di seluruh organisasi. Serta mengembangkan kegiatan usaha, aliran material, keuangan, dan informasi yang mendukung operasional akan membantu dengan penampilan ERP (Shen., Et al, 2016).

Selain itu, penerapan sistem ERP tidak hanya meningkatkan kepuasan pelanggan dan mengurangi biaya operasional, tetapi juga akhirnya menghasilkan peningkatan keuntungan dan pertumbuhan organisasi. Selanjutnya peningkatan produktivitas, mengurangi kesalahan dan ketersediaan waktu yang konsisten telah menjadi manfaat yang terkait dengan sistem ERP (Davenport, T. H,. 2000).

\subsection{SAP (System Application and Product)}

SAP terdiri dari sejumlah modul / aplikasi yang mempunyai kemampuan mendukung semua transaksi yang perlu dilakukan suatu perusahaan dan tiap aplikasi bekerja secara berkaitan satu dengan yang lainnya (Seto, 2013). Sedangkan pengertian dari modul di dalam SAP adalah suatu unit piranti lunak yang berdiri sendiri dari model, tampilan, dan pendukung lainnya (Yii, 2009).

Jadi, kesimpulannya SAP merupakan suatu produk perangkat lunak atau software yang digunakan perusahaan dalam mempermudah kinerja pegawai dalam mencapai tujuan yang diharapkan. Dengan adanya suatu produk perangkat lunak maka pegawai tidak akan kesulitan dan lama dalam mengolah data - data yang berhubungan dengan kepegawaian ataupun yang lainnya. SAP memiliki beberapa keuntungan diantaranya adalah : 
a. SAP terdiri dari sejumlah modul / aplikasi yang mempunyai kemampuan mendukung semua transaksi yang perlu dilakukan suatu perusahaan dan tiap aplikasi bekerja secara berkaitan satu dengan yang lainnya.

b. SAP mempunyai netweaver platform, yang men-support development dan software logistic.

c. SAP mempunyai ABAP atau programmer, yang mempermudah developer untuk implementasi business logic.

d. Mendukung integrasi proses bisnis perusahaan - perusahaan besar.

e. Semua informasi yang tersimpan di dalam SAP dapat diakses oleh bagian organisasi yang membutuhkan pada saat dibutuhkan (Seto, 2013).

\section{METODE PENELITIAN}

Metode dalam penyusunan demografi organisasi dengan melakukan telaah jurnal jurnal yang berkaitan dengan ERP SAP, dan demografi organisasi sebagai dasar teoritis sebelum dilakukan evaluasi dan proses penyusunan.

Tahap selanjutnya adalah membuat report demografi organisasi di SAP dengan mengikuti sistim prosedur yang berlaku di Perusahaan. Hal ini dilakukan agar implementasi dapat dilakukan dengan benar sehingga tidak ditemui kendala di masa yang akan datang.

\subsection{Pembuatan Transaksi Report Demografi Di ERP SAP}

a. Perancangan Report Demografi

Report demografi organisasi yang dibutuhkan bagi manajemen dalam melakukan evaluasi diperlukan informasiinformasi sebagai berikut :

a. Usia tenaga kerja pada organisasi terebut.

b. Jumlah karyawan setiap golongan atau level pada organisasi tertentu untuk dapat dilakukan perhitungan staffing level. c. Tanggal mulai bekerja untuk dapat dilakukan perhitungan kapan karyawan pada organisasi tertentu akan pensiun.

d. Tanggal menempati posisi jabatan untuk dapat dilakukan perhitungan lenght of service.

\subsection{Evaluasi Proses}

Penyusunan report demografi organisasi selama ini menggunakan metode manual yaitu dengan mengolah manning table yang diturunkan dari SAP (belum dibuat transaksi khusus untuk report demografi), dilakukan dengan proses terdapat pada gambar 3 dan 4 .

Dengan mempergunakan proses seperti pada gambar 3 dan 4, terdapat beberapa kelemahan yaitu :

a. Memerlukan waktu yang relatif lama dalam penyusunannya.

b. Tidak real time karena masih bergantung pada hasil download manning table yang kemudian diolah lebih lanjut.

c. Tingkat kesalahan dalam mengklasifikasikan atau menggolongkan ke dalam range usia maupun golongan sangat besar, karena sangat bergantung terhadap ketelitian pengolah data.

\subsection{Pembuatan Report Demografi di SAP}

Permintaan pembuatan report atau transaksi di SAP dilakukan dengan terlebih dahulu mendeskripsikan hal yang dinginkan pada suatu form yang bernama Functional Specification (FS) terdapat pada gambar 5 dan gambar 6.

Di dalam form FS ini akan diminta nama dari report atau transaksi yang diminta, alasan permintaan (untuk alasan permintaan adalah lack of essential business information seperti yang telah dijelaskan diatas mengenai demografi), output yang diinginkan termasuk data yang dinginkan diperoleh dari mana dan apabila terdapat perhitungan yang dilakukan, harus dimasukkan cara perhitungannya (gambar 7). 


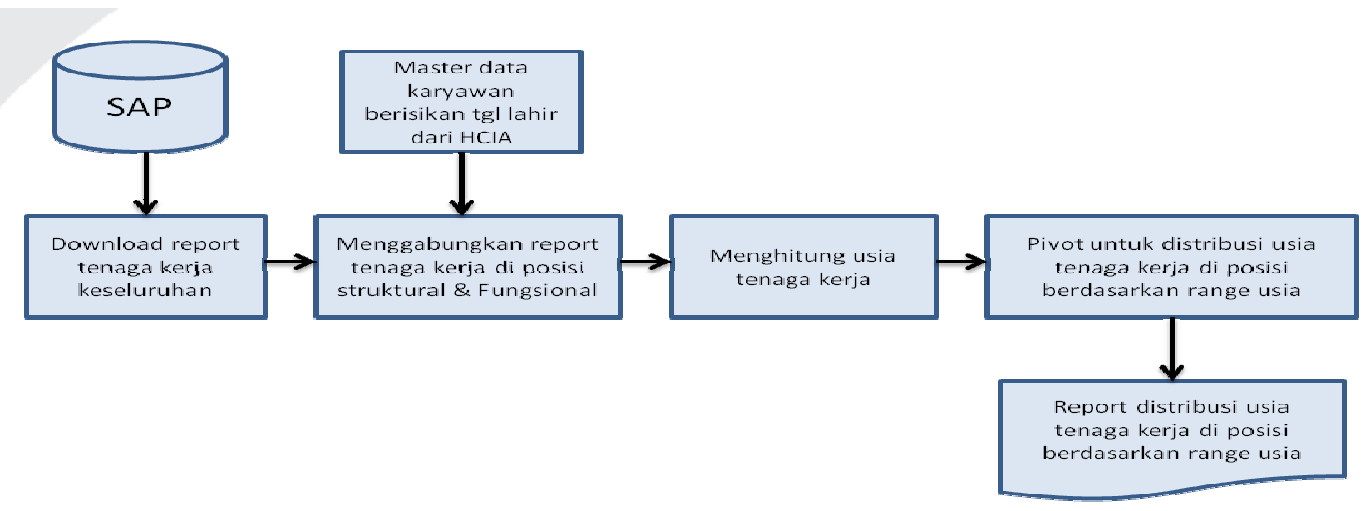

Gambar 3. Proses Penyusunan Report Demografi untuk Jumlah Karyawan.

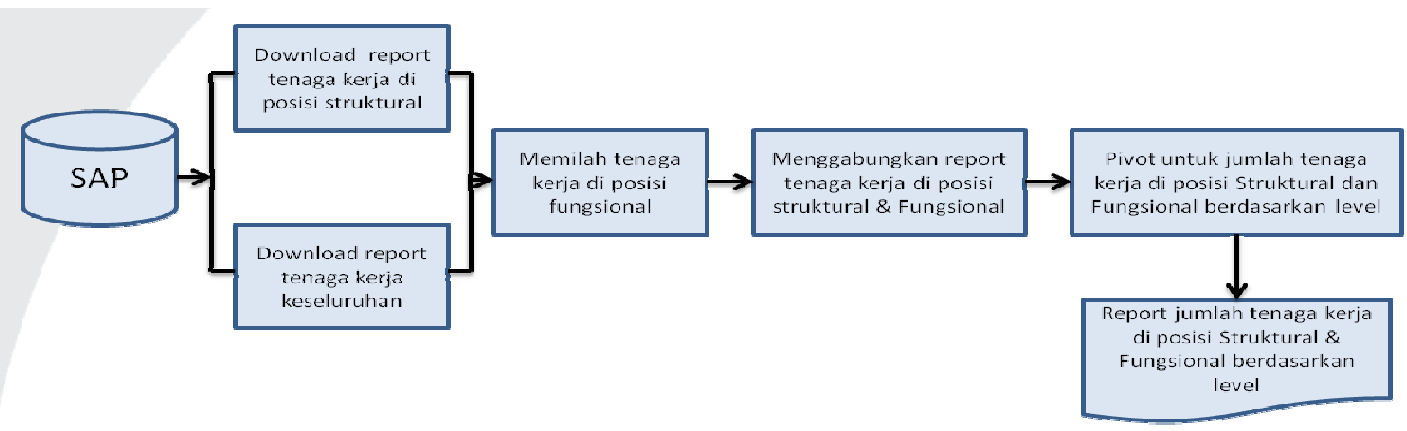

Gambar 4. Proses Penyusunan Report Demografi untuk Usia Karyawan.

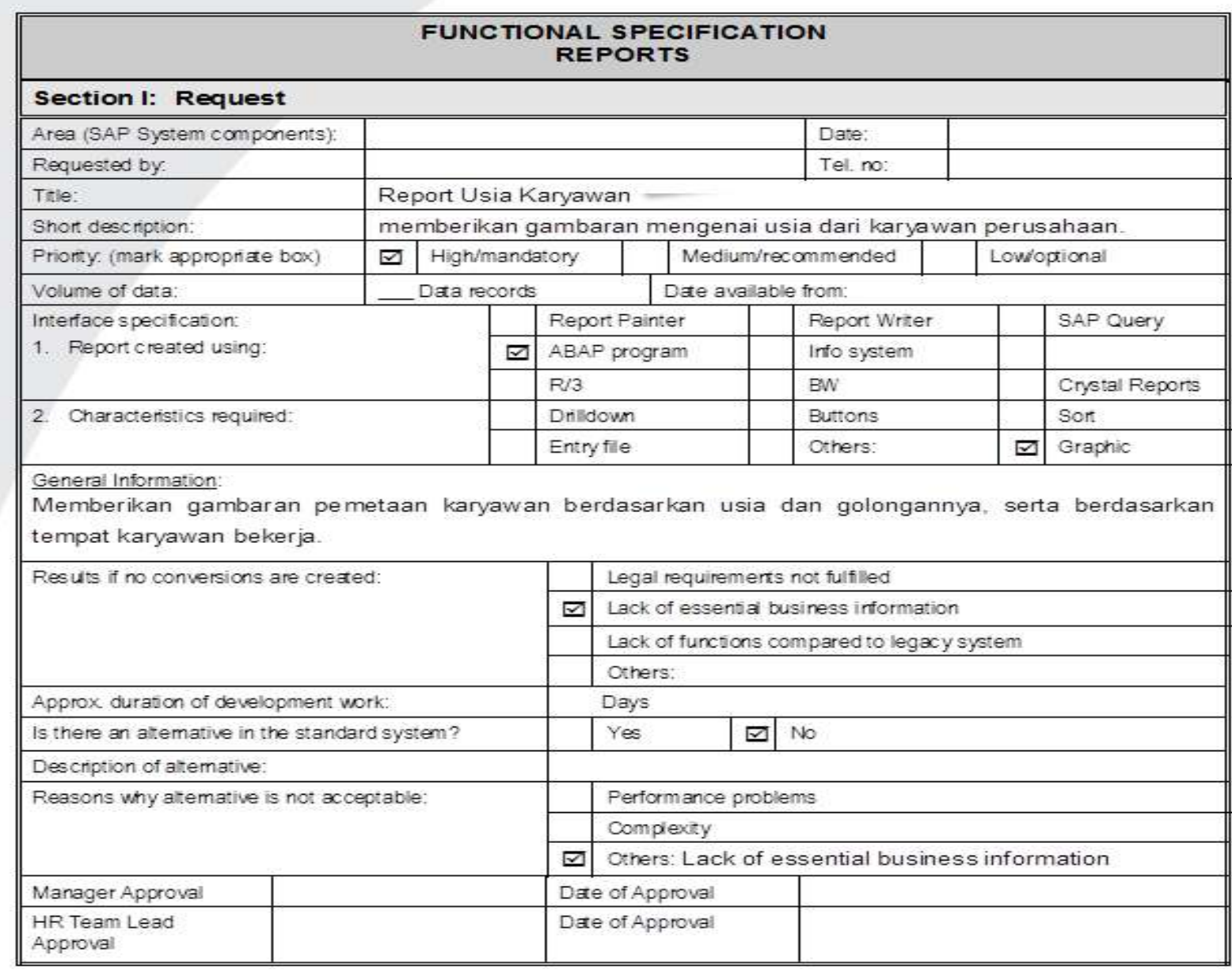

Gambar 5. Functional Specification. 
Setelah Functional Specification tersebut disetujui (approval dari pihak pihak terkait), maka akan dilakukan pembuatan transaksi untuk report tersebut, kemudian setelah transaksi selesai dibuat dilakukan pengetesan terhadap transaksi tersebut untuk mengetahui kesesuaian antara hasil yang diperoleh dengan yang dinginkan.

\subsection{Hasil Pembuatan Report Demografi}

Setelah dilakukan pembuatan transaksi report demografi di SAP dan dilakukan run test. Setelah sesuai dan berjalan dengan baik, maka transaksi tersebut dinaikkan ke production. Hasil yang diperoleh dapat dilihat pada gambar 8 dan gambar 9 .

\section{HASIL DAN PEMBAHASAN}

Informasi yang diperlukan dalam demografi, setelah dilakukan cross check dengan hasil telaah jurnal yang berkaitan dengan demografi dan komitmen organisasi, maka informasi - informasi pada report telah sesuai.

Pembuatan report demografi di SAP, dapat mempercepat proses. Hal ini dapat dilihat dari perbandingan proses antara sebelum dan sesudah, seperti yang ditunjukkan pada gambar 10 dan 11 di bawah.

Perbaikan proses dalam pembuatan report dengan mengoptimalkan ERP SAP, selain dapat memperpendek proses, juga dapat mempersingkat waktu pembuatan dari semula memerlukan waktu 30 menit menjadi hanya diperlukan waktu kurang dari menit, atau proses menjadi lebih cepat $30 \mathrm{x}$ dari waktu sebelumnya.

Tingkat kesalahan yang dapat timbul dari pembuatan report demografi organisasi juga dapat ditekan dikarenakan pembuatan report demografi ini dilakukan sepenuhnya oleh aplikasi.

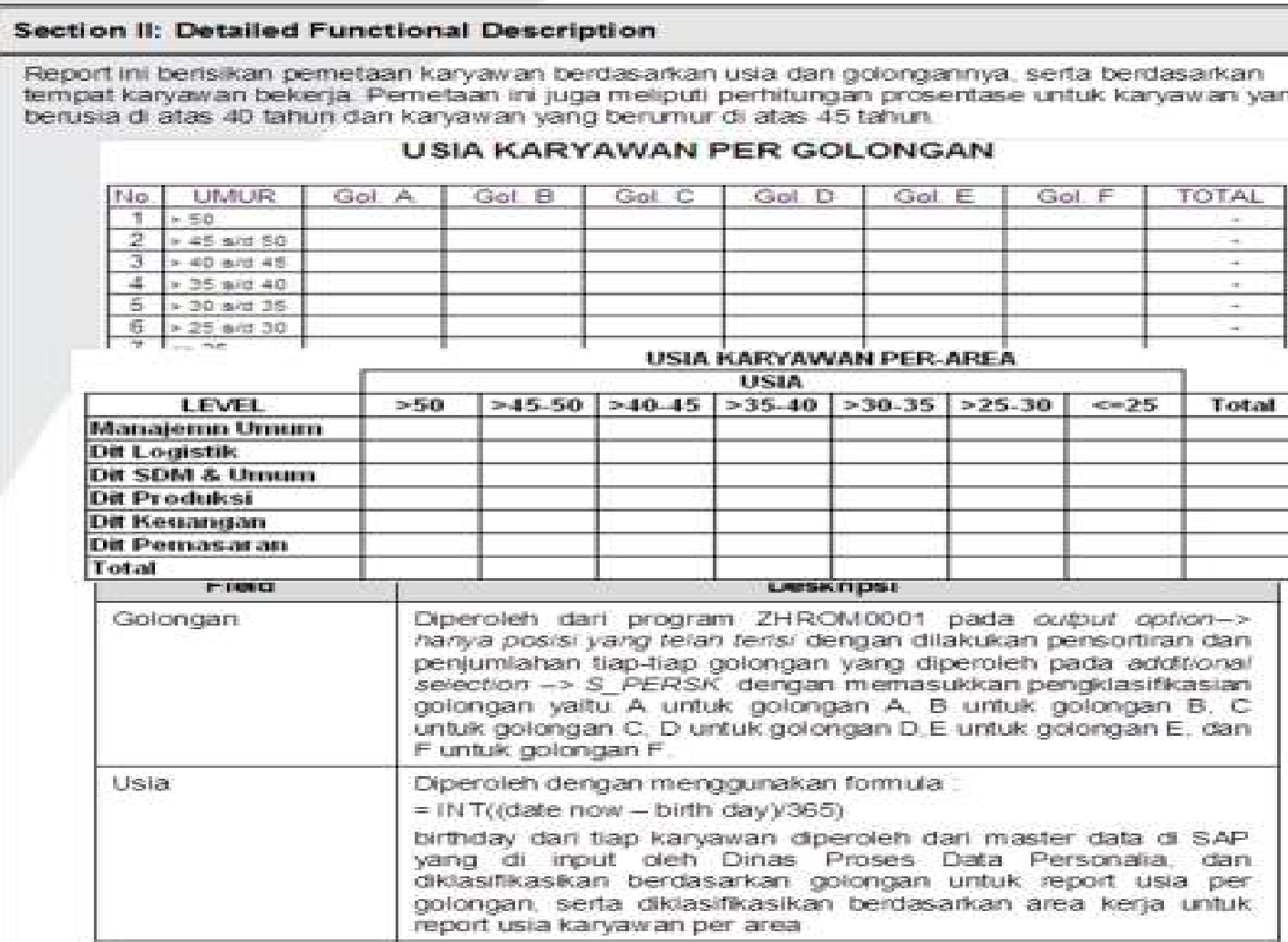

Gambar 6. Detailed Functional Specification. 
Teknoin Vol. 23 No. 3 September 2017 : 241 - 252

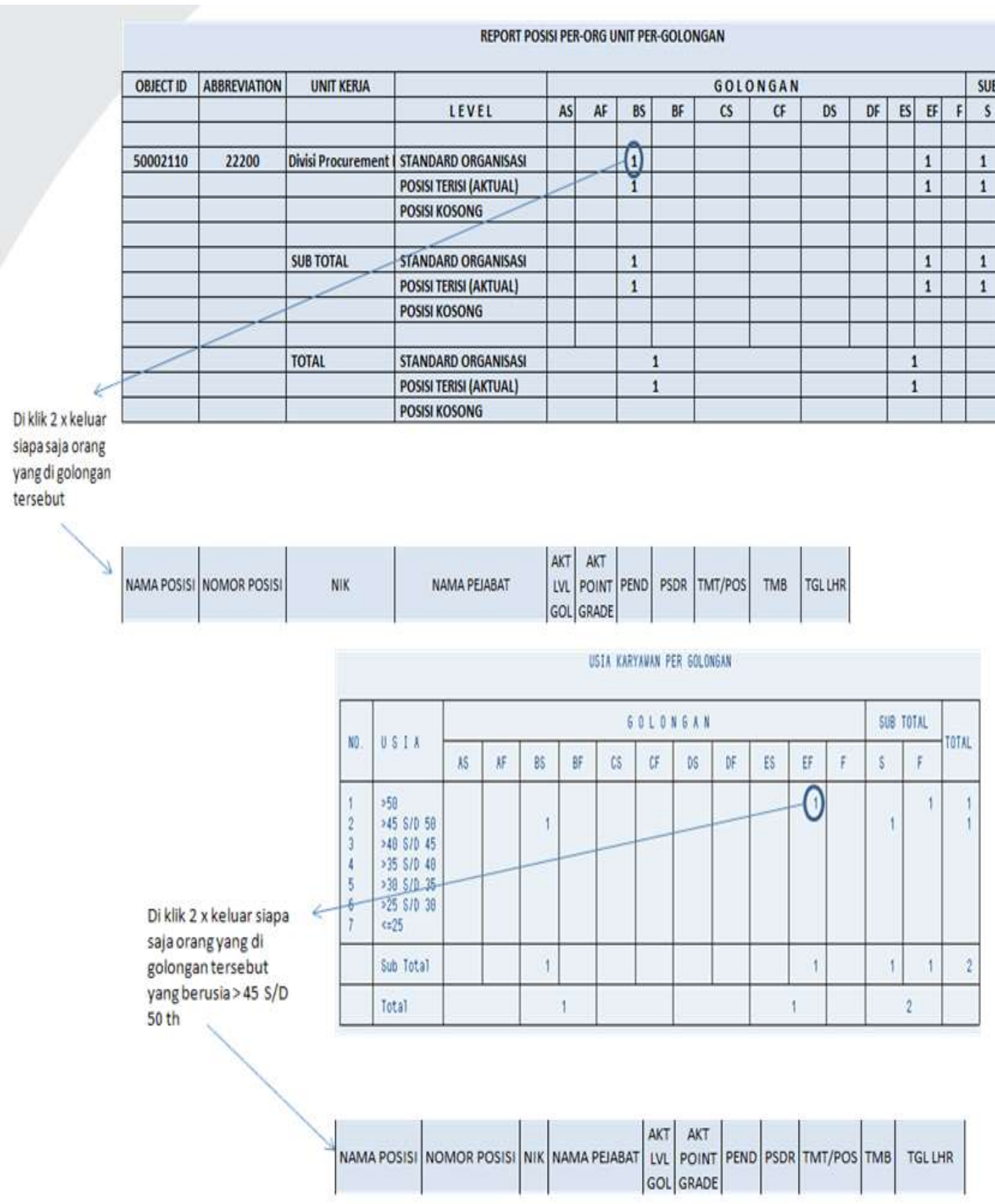

Gambar 7. Tampilan Report Demografi yang Diinginkan. 


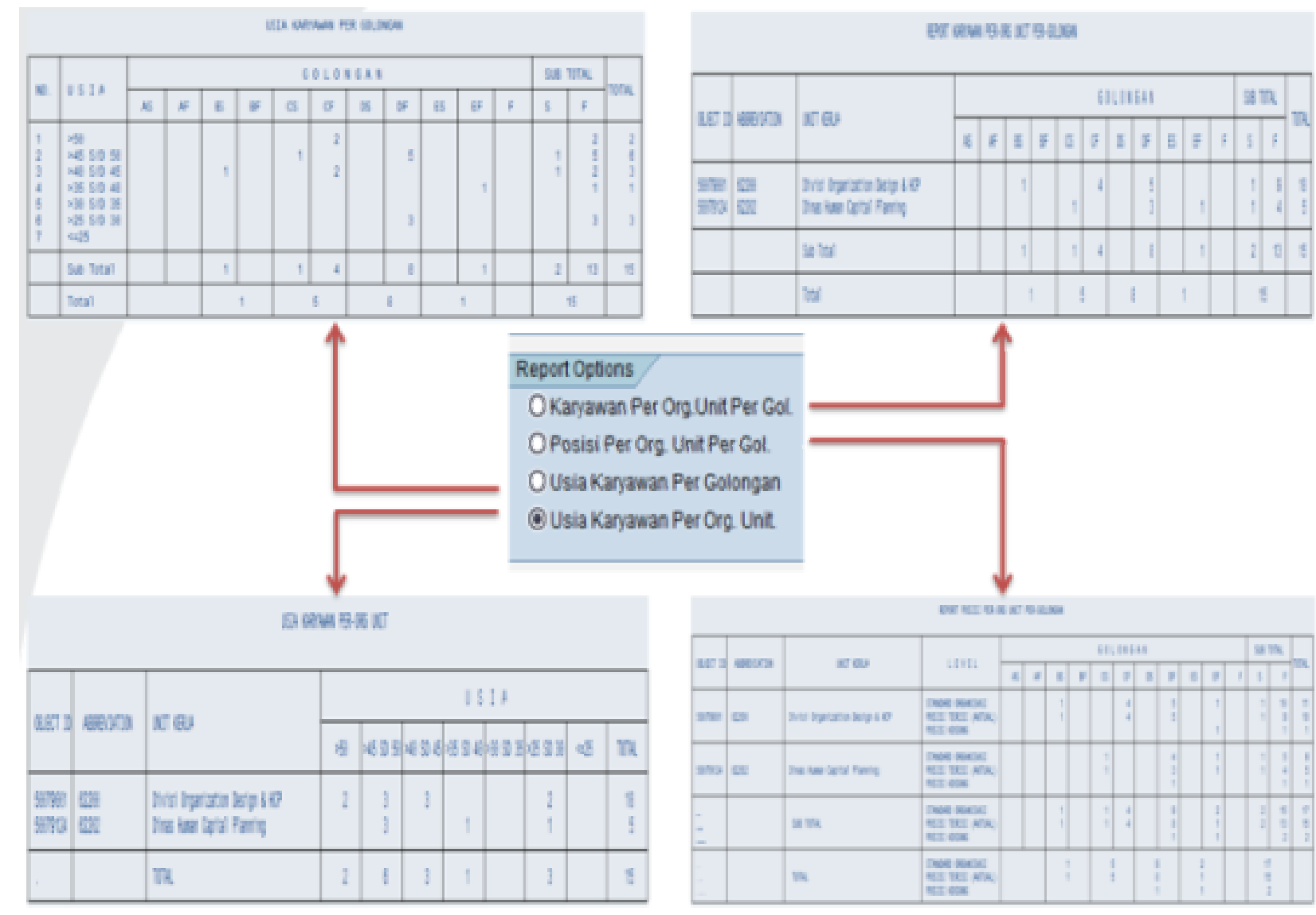

Gambar 8. Tampilan Report Demografi yang Diinginkan.

\begin{tabular}{|c|c|c|c|c|c|c|c|c|c|c|c|c|c|c|c|}
\hline \multicolumn{16}{|c|}{ 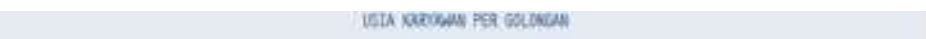 } \\
\hline \multirow{2}{*}{$\mathrm{n}$} & \multirow{2}{*}{ U5tA } & \multicolumn{11}{|c|}{$0000 \times 0 \times 1$} & \multicolumn{2}{|c|}{ 2at sork } & \\
\hline & & as & H & 85 & EF & af & \# & 26 & to & t5 & E & if & $s$ & f & \\
\hline \multirow[t]{3}{*}{$\begin{array}{l}\vdots \\
\vdots \\
\vdots\end{array}$} & 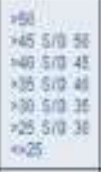 & & & 1 & & 1 & $\frac{2}{2}$ & & 3 & & 1 & & $\vdots$ & $\begin{array}{l}\frac{2}{3} \\
\frac{1}{1} \\
3\end{array}$ & $\begin{array}{l}2 \\
\frac{2}{2} \\
3 \\
1\end{array}$ \\
\hline & Sat Tots & & & 1 & & 1 & + & & 1 & & t & & 2. & 0 & C \\
\hline & Tora? & & & a & 1 & 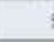 & 5 & & 1 & & 1 & & 1 & : & \\
\hline
\end{tabular}

Jika menginginkan detail karyawan, klik dua kali di angka yang tertera di report tersebut, maka akan muncul detail sebagai berikut.

\section{USIA KARYAWAN PER-GOLONGAN}

\begin{tabular}{|c|c|c|c|c|c|c|c|c|c|c|}
\hline RaALA FOSIS: & POSi5: & NIK RLILAKAFECAWNI & AKT GOL & AKT GEA & PEVDOI & PGOS & MTPOS & THe & TCLLAHAR & USA \\
\hline Hanager Organiessan Design 8 HCP & 6220000005 & & & & si & $\$ 2$ & 01.102059 & 07.121992 & 18.05 .1967 & 44 \\
\hline Sr Specatist Organcation Desiggn & 620120005 & & & & SLTA & S1 & 21072010 & 17061582 & 2411.1960 & 51 \\
\hline Sr Specjalist Organcation Design & 6220020000 & & & & D3 & s1. & 04032011 & $30.06+593$ & 1609.1959 & 52 \\
\hline Sr Specialist Orpanzation Desig̨n & 6220020000 & & & & St & & 28102069 & 02021395 & 2401.1967 & 44 \\
\hline Sprozist jab Anakbis & 5220021002 & & & & \$1 & & 10002.2010 & 19082508 & 05.07 .1984 & 27 \\
\hline Spedast job Analisa & 6220121005 & & & & SLTA & & 02122010 & 07021583 & 02011961 & 50 \\
\hline Sproaliat Jao Ahalysis & 6220121000 & & & & D3. & 91 & 26.102099 & 17.07 .1590 & 31.121961 & 49 \\
\hline Speoalat job Analjas (Ona) & 6220021000 & & & & 81 & & 01.112011 & 01112011 & 27.05 .1985 & 26 \\
\hline Sr Speosist Jop Ralesuintheritaton V & 6220020005 & & & & si & & 28042011 & 01111993 & 12.10 .1967 & 4 \\
\hline Specalast job Role 3 . Authorzason Hg & 6220021005 & & & & sith & $\$ 1$ & 01052011 & 0307,5505 & 18.07 .1965 & 45 \\
\hline Superintendemt Human Cashai Piann & 6220200005 & & & & si & $\$ 2$ & 04,032011 & 07,121992 & $17,07,1965$ & 45 \\
\hline Epcoalat Human Capta Pumieg & 6220201000 & & & & \$1 & & 19682010 & 19062006 & 18.05 .1965 & 2 \\
\hline Specaast Human Capta Plarning & 5220201002 & & & & D3 & & 22.102089 & 10.121384 & 26.031961 & 50 \\
\hline Sptoaist Human Captal Plamieg & 6220201005 & & & & SLTh & S1 & 17032011 & 02011389 & 21.02 .1964 & 47 \\
\hline Ofcer Human Castal Planning & 6220201100 & & & & SLTh & s1 & 03122010 & 01.11 .1995 & 20.081973 & 30 \\
\hline
\end{tabular}

Gambar 9. Detil Tampilan Report Demografi yang Diinginkan. 


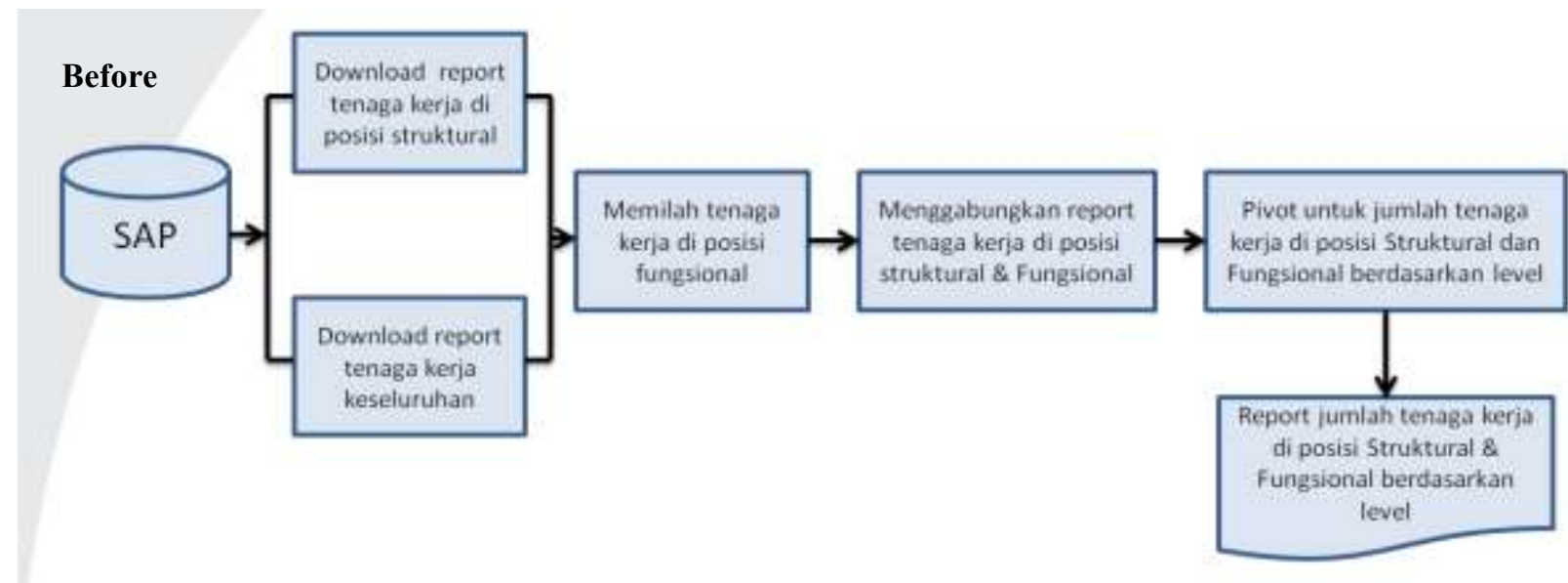

After

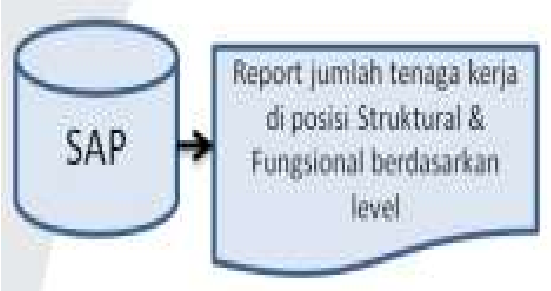

Gambar 10. Perbandingan Proses Pembuatan Report Demografi Level.

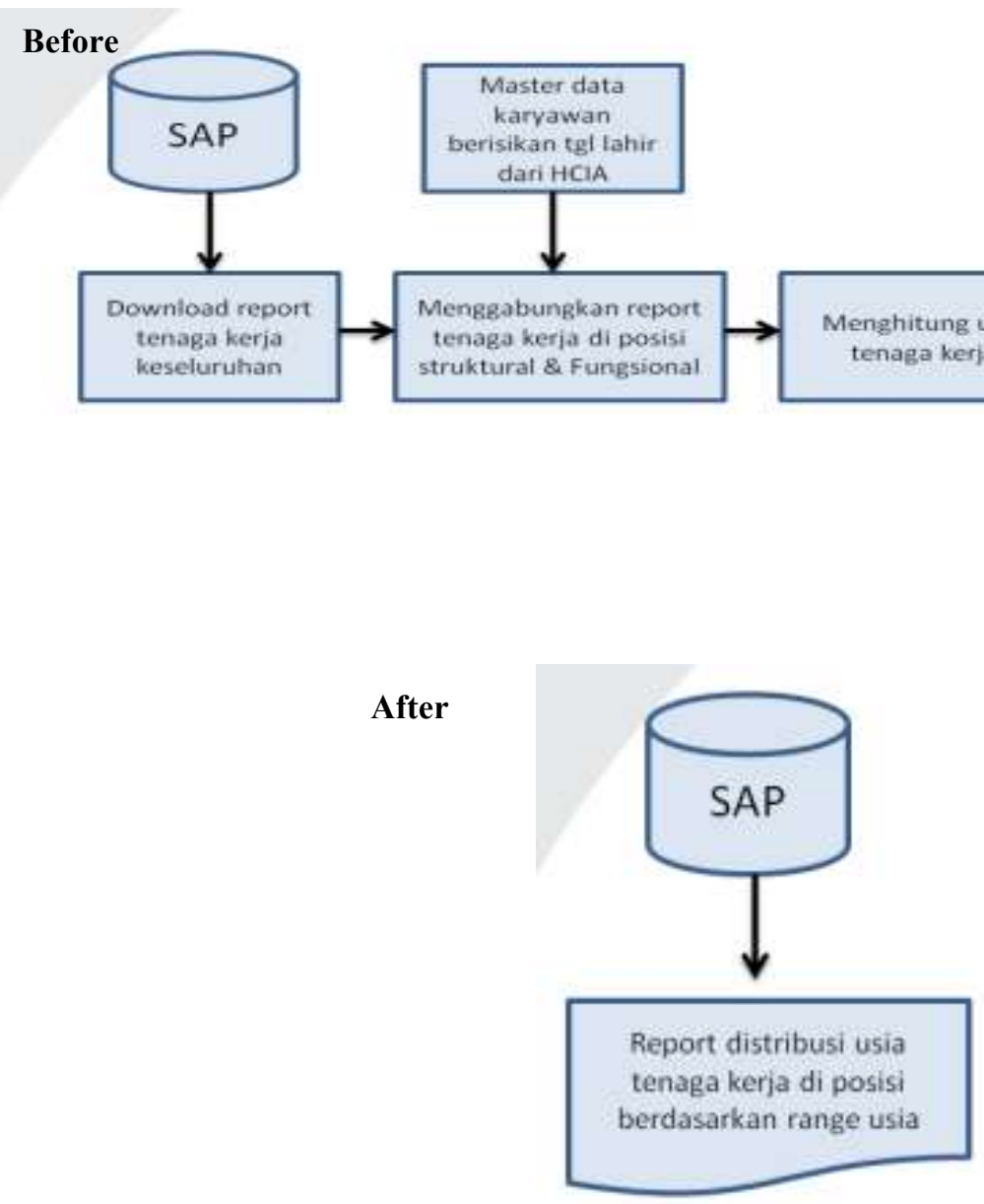

Gambar 11. Perbandingan Proses Pembuatan Report Demografi Usia. 


\section{KESIMPULAN}

Pembuatan report demografi organisasi dengan mengoptimalkan ERP SAP seperti yang telah dijelaskan diatas diperoleh beberapa manfaat sebagai berikut :

1. Mempendek proses dan mempersingkat waktu.

2. Real time report dapat dilakukan, sehingga kebutuhan akan informasi secara real time dapat terpenuhi.

3. Tingkat kesalahan dalam pembuatan report demografi organisasi dapat ditekan.

4. Dengan percepatan waktu proses dan pengurangan tingkat kesalahan, maka produktivitas kerja dari karyawan yang melakukan tugas menyusun demografi organisasi meningkat.

\section{DAFTAR PUSTAKA}

Bernabe, J. B., Perez, J. M. M., Calero, J. M. A., Clemente, F. J. G., Perez, G. M., \& Skarmeta, A. F. G., 2014. Semantic-aware multi-tenancy authorization system for cloud architectures. Future Generation Computer Systems, 32, 154-167.

Davenport, T. H., 1993. Process innovation: reengineering work through information technology. Harvard Business Press.

Galbraith, J. R., 1977. Organization design. Addison Wesley Publishing Company.

Horton, Paul B. \&Chester L. Hunt., 1984. Sociology. Edisi keenam. International Student Edition. Tokyo: Mc.Graw-Hill Book Company Inc.Hlm. 89).
Konya, V., Matić, D., \& Pavlović, J., 2016. The influence of demographics, job characteristics and characteristics of organizations on employee commitment. Acta Polytechnica Hungarica, 13(3), 119 - 138.

Nanda,Putri Prameswari Sri Rahayu Tri Astuti., 2011). Analisis Faktor Faktor yang Mempengaruhi Loyalitas Konsumen Pada Asuransi "P" di Kota Semarang.Jurnal Fokus Ekonomi. Vol.6.Nomor 2.Desember.

O'Brien, J. A., \& Marakas, G. M., 2005. Introduction to information systems (Vol. 13). New York City, USA : McGraw-Hill / Irwin.

Robbins, S. P., 1994. Teori organisasi: struktur, desain dan aplikasi. Jakarta: Arcan.

Seto, Indiwan., 2013. Semiotika Komunikasi Aplikasi Praktis Bagi Penelitian dan Skripsi Komunikasi. Jakarta : Mitra Wacana Media.

Shen, Y.-C., Chen, P.-S., \& Wang, C.-H., 2016. A study of enterprise resource planning (ERP) system performance measurement using the quantitative balanced scorecard approach. Computers in Industry, 75, 127-139.

Singarimbun, M., \& Efendi, S., 1976. Understanding Practice and Analysis.

Sukoco, Badri Munir., 2007. Manajemen Administrasi Perkantoran Modern. Jakarta: Erlangga.

Tarigan, S., 2011. Pengaruh Pengalaman Kerja, Independensi, Objektivitas, Integritas Dan Kompetensi Terhadap Kualitas Hasil Pemeriksaan (Master's thesis). 
Utami, S. S., \& Susilo, H., 2016. Analisis Penerapan Enterprise Resource Planning (Erp) (Studi Pada PT Domusindo Perdana). Jurnal Administrasi Bisnis, 33(1), 165-170.

Wallace, T. F., \& Kremzar, M. H., 2002. ERP: making it happen: the implementers' guide to success with enterprise resource planning (Vol. 14). John Wiley \& Sons.

Wilis Dahar, R., 1996. Teori - teori belajar. Jakarta: Erlangga.

Yakub., 2012. Pengantar Sistem Informasi. Yogyakarta : Graha Ilmu. 